\title{
TEORIA DOS PRECEDENTES E SUA INCOMPATIBILIDADE COM O SISTEMA DELIBERATIVO DOS TRIBUNAIS SUPERIORES
}

\author{
THEORY OF PRECEDENTS AND ITS INCOMPATIBILITY WITH THE \\ DELIBERATIVE SYSTEM OF THE HIGHER COURTS
}

\section{TEORÍA DE LOS PRECEDENTES Y SU INCOMPATIBILIDAD CON EL SISTEMA DELIBERATIVO DE LOS TRIBUNALES SUPERIORES}

\begin{abstract}
GILBERTO ANDREASSA JUNIOR
Doutorando (PUC/PR) e Mestre (UniBrasil) em Direito. Pós-graduado em Direito Processual Civil Contemporâneo (PUC/PR). Membro Efetivo do Instituto dos Advogados do Paraná. Membro Honorário da Academia Brasileira de Direito Processual Civil. Advogado e Professor Universitário. (Curitiba, Paraná, Brasil). http://lattes.cnpq.br/8902400311996910 / http://orcid.org/0000-0003-0166-5824 / gilbertoajunior@gmail.com
\end{abstract}

Claudia Maria Barbosa

Pós-Doutorado na York University (Toronto - Canadá). Mestre e Doutora em Direito (UFSC). Membro do Trustee Committee da Law and American Society. Co-fundadora do Instituto Brasileiro de Administração do Sistema Judiciário - IBRAJUS. Professora titular de Direito Constitucional da Pontifícia Universidade Católica do Paraná.

(Curitiba, Paraná, Brasil).

http://lattes.cnpq.br/0016091493799961 / http://orcid.org/0000-0002-7055-9403 / claudia.mr.barbosa@gmail.com

\section{RESUMO}

O presente artigo é fruto de uma discussão que vem tomando conta dos operadores do direito, pois como é possível cada tribunal julgar de forma diversa matérias idênticas? A resposta se dá ao fato de que no Brasil não se buscou analisar os métodos de formulação dos precedentes, os quais são tão bem utilizados no sistema de common law. 0 que se propõe, na realidade, é demonstrar que as atuais reformas legislativas são insuficientes para gerar um Poder Judiciário seguro e coerente. Também se busca demonstrar a impossibilidade de aplicação da teoria dos precedentes no atual sistema deliberativo dos tribunais superiores. 0 método utilizado decorre de revisão bibliográfica, estudo de casos e jurisprudência.

Palavras-chave: Civil law; Common law; Jurisprudência; Precedentes; Sistemas.

\begin{abstract}
This article is the result of a discussion that has been taking account of judiciary, because how is it possible for each court to give a different judgment on identical matters? The answer is given to the fact that in Brazil is not intended to analyze the methods of the precedents, which are so well used in the common law system. What it proposes, in fact, is to demonstrate that the current legislative reforms are insufficient to generate a secure and coherent Judicial Power. It also seeks to demonstrate the impossibility of applying the theory of precedents in the current deliberative system of higher courts. The method used is based in bibliographic review, case studies and jurisprudence.
\end{abstract}

Keywords: Civil law; Common law; Jurisprudence; Precedents; Systems.

\section{RESUMEN}

El presente artículo es fruto de una discusión que viene tomando cuenta de los operadores del derecho, ¿cómo es posible cada tribunal juzgar de forma diferente materias idénticas? La respuesta se da al hecho de que en Brasil no se buscó analizar los métodos de formulación de los precedentes, los cuales son tan bien utilizados en el sistema de common law. Lo que se propone, en realidad, es demostrar que las actuales reformas legislativas son insuficientes para generar un Poder Judicial seguro y coherente. También se busca demostrar la imposibilidad de aplicación de la teoría de los precedentes en el actual sistema deliberativo de los tribunales superiores. El método utilizado procede de revisión bibliográfica, estudio de casos y jurisprudencia.

Palabras clave: Civil law; Common law; Jurisprudencia; Sistemas. 


\section{SUMÁRIO}

INTRODUÇÃO; 1 PRECEDENTES JUDICIAIS NO SISTEMA JURÍDICO ANGLO-AMERICANO (STARE DECISIS); 1.1 Conceito; 1.2 Ratio decidendi e Obiter dictum; 1.3 Overruling e Distinguishing; 2 OS “PRECEDENTES” NO SISTEMA JURÍDICO BRASILEIRO (STF E STJ); 2.1 Precedentes no Supremo Tribunal Federal; 2.1.1 Decisão proferida no controle difuso de constitucionalidade; 2.1.2 Decisão proferida no controle concentrado de constitucionalidade; 2.1.3 A repercussão geral; 2.1.4 Súmulas; 2.1.5 Súmulas vinculantes; 2.1.6 Recursos repetitivos; 2.1.7 Incidente de assunção de competência; 2.1.8 Decisões de plenário ou de órgão especial; 2.2 Precedentes no Superior Tribunal de Justiça; 2.2.1. Recursos repetitivos, súmulas e incidente de assunção de competência; 2.2.2 Relevância da questão federal; 3 PENSAMENTOS CRÍTICOS E PROPOSTAS DE REGULAMENTAÇÃO DOS PRECEDENTES; CONCLUSÃO; REFERÊNCIAS.

\section{INTRODUÇÃO}

O ordenamento jurídico brasileiro surgiu da tradição romano-germânica e, por conseguinte, se baseia na lei escrita e promulgada pelo Estado.

Não bastasse a existência dos mais diversos Códigos e normas, o Direito Processual brasileiro, nos últimos tempos, vem passando por sensíveis modificações voltadas a imprimir segurança jurídica, isonomia, celeridade e efetividade processual.

Ocorre, porém, que utilizando as mais variadas reformas - em especial a criação de um novo Código de Processo Civil -, membros do Poder Judiciário vêm descumprindo ao que denominamos de devido processo legal, sob o fundamento de que estão seguindo precedentes judiciais, tais como decisões pacificadas (ou repetitivas) e súmulas vinculantes. ${ }^{1} \mathrm{Na}$ realidade, grande parcela dos juristas confunde a ideia de jurisprudência e decisões vinculantes com os precedentes, possivelmente porque possuem uma formação totalmente voltada à codificação.

O que se propõe no presente estudo é demonstrar a aplicação equivocada da teoria dos precedentes no ordenamento jurídico nacional. Não há como se falar em justiça, democracia e direitos humanos sem a viabilidade de um processo justo e igualitário a todos os cidadãos.

Não obstante o Código de Processo Civil/2015 tenha trazido relevantes alterações para o sistema de julgamentos nos tribunais superiores, muito ainda precisa ser melhorado, sobretudo porque ainda há margem para que os julgadores continuem atuando de forma individual sem

\footnotetext{
${ }^{1}$ De fato, no Brasil está se vivenciando um momento de massificação das demandas judiciais. A forma utilizada pelo Estado para superar a chamada "crise do Judiciário" é o fortalecimento dos "precedentes" no Direito Brasileiro, que permitirão uma maior celeridade de julgamento, especialmente das demandas de massa (consumeristas e previdenciárias, por exemplo).
} 
qualquer preocupação com a segurança jurídica e, principalmente, integridade das decisões. Surgiu o momento de discutir os motivos pelos quais, apesar da evolução do nosso direito, muitos convivem naturalmente com um direito incoerente e com um sistema judicial despido de racionalidade.

O objetivo da pesquisa não é afastar o sistema do civil law no Brasil, até porque muitos benefícios podem ser extraídos do sistema codificado. 0 objetivo é, sim, demonstrar que o modelo atual de deliberação nos tribunais superiores - em especial no Supremo Tribunal Federal - impede a recepção da teoria dos precedentes, a qual está intimamente vinculada ao common law. Ainda, busca-se fazer uma reflexão crítica a partir da aproximação dos sistemas no Brasil e, acima de tudo, propor a unificação dos dois principais sistemas jurídicos, a fim de implementar a verdadeira teoria dos precedentes que, com cautela e estudo aprofundado, pode ser recepcionada pelo Judiciário brasileiro.

\section{PRECEDENTES JUDICIAIS NO SISTEMA JURÍDICO ANGLO-AMERICANO} (STARE DECISIS) ${ }^{2}$

\subsection{Conceito}

Antes de adentrar ao tema, vale informar que common law e stare decisis não se confundem. "O stare decisis constitui apenas um elemento do moderno common law, que também não se confunde com o common law de tempos imemoriais ou com os costumes gerais, de natureza secular, que dirigiam o comportamento do Englishmen". ${ }^{3}$

Pois bem. Embora o termo precedente seja polissêmico, em uma breve leitura dos seus requisitos formais já podemos distingui-lo da jurisprudência. De forma sucinta, podemos

\footnotetext{
${ }^{2}$ Não obstante pequena parte da doutrina diferenciar o termo stare decisis de precedente, no presente trabalho as nomenclaturas serão tratadas como sinônimo. "Comumente, fala-se de stare decisis e precedente como termos quase análogos, tal como defende Neil Duxbury (...). Na mesma direção trafega a concepção de Melvin Aron Eisenberg (...). Contudo, há certa divergência no entendimento defendido por Frederick Schauer, o qual percebe diferenças entre precedente e stare decisis. Tecnicamente, a obrigação de uma corte de seguir decisões prévias da mesma corte é referida como sendo stare decisis, e o termo mais abrangente precedente é usado para se referir tanto à stare decisis, quanto à obrigação de uma corte inferior de seguir decisões de uma superior". ODAHARA, Bruno Periolo. Um rápido olhar sobre o stare decisis. In: MARINONI, Luiz Guilherme. A força dos precedentes: estudos dos cursos de Mestrado e Doutorado em Direito Processual Civil da UFPR. 2. ed. Salvador: JusPodivm, 2012. p. 86-88.

${ }^{3}$ MARINONI, Luiz Guilherme. Precedentes obrigatórios. 2. ed. São Paulo: Revista dos Tribunais, 2011. p. 34.
} 
delimitar o precedente como decisão anterior que funciona como modelo (potencialidade de influência) ${ }^{4}$ para decisões posteriores (isonomia - treat like cases alike). ${ }^{5}$

Para Joel Prentiss Bishop, o common law - que é o sistema que melhor utiliza a ideia do stare decisis - se funda principalmente na racionalidade (indução) enquanto o civil law e suas codificações se fundam no comando (dedução). ${ }^{6}$ Conforme Camargo, uma

distinção básica entre precedente e jurisprudência reside na circunstância de que enquanto um precedente é substantivo singular, a jurisprudência é substantivo coletivo, e, para ser corretamente denominada como tal, deve se constituir de um conjunto de decisões ou acórdãos uniformes, que reflitam o pensamento dominante de determinado tribunal ou, se possível, do Poder Judiciário inteiro. ${ }^{7}$

Ronald Dworkin, um dos maiores filósofos da história contemporânea, direciona a ideia de precedentes como um romance em cadeia, isto é, cada julgador deve agir como se estivesse escrevendo o capítulo de um romance, devendo para tanto partir do capítulo anterior, para poder avançar. ${ }^{8}$

Ao tratar o Direito como integridade, pode-se afirmar que o sistema mais próximo do ideal é o common law, haja vista que este sistema é formado por uma comunidade de princípios para além do texto escrito na Constituição.

Dworkin ainda cita a força gravitacional dos precedentes. ${ }^{9}$ Para o autor, não é só o dispositivo da decisão que possui validade e importância jurídica para casos futuros, mas também os princípios que embasaram o precedente. $^{10}$

\footnotetext{
${ }^{4}$ Quem firma um precedente não apenas deixa registrado como se comportará diante de novos casos, mas adquire uma grande responsabilidade em relação ao futuro. BENDITT, Theodore $M$. The rule of precedent. Precedent in law. Oxford: Clarendon Press, 1987. p. 95.

5 "Precedents are prior decisions that function as models for later decisions". MACCORMICK, Neil; SUMMERS, Robert S. (Coord.). Interpreting precedents: a comparative study. London: Dartmouth, 1997. p. 1.

${ }^{6}$ BISHOP, Joel Prentiss. Common law and codification or the Common law as a system of reasoning How and why essential to good government; what its perils, and how averted. Chicago: Law Book Publishers, 1888. p. 3-4.

${ }^{7}$ CAMARGO, Luiz Henrique Volpe. A força dos precedentes no moderno processo civil brasileiro. In: Teresa Arruda Alvim Wambier (Coord.). Direito jurisprudencial. São Paulo: Revista dos Tribunais, 2012. p. 556.

${ }^{8}$ DWORKIN, Ronald. 0 império do direito. 2. ed. São Paulo: Martins Fontes, 2010. p. 275.

9 "Aquele esforço conduzido por juízes, como descrito por Dworkin, está, acreditamos, no centro da consistência. A força gravitacional do precedente induz os juízes a decidirem de modo mais coerente com o sentido geral e raciocínio de outras decisões. Em certo sentido, acreditamos e propomos que a força gravitacional dos precedentes leva os juízes a seguirem a correnteza, mas não obstante deixa espaço para tentarem mudar o rumo da correnteza". LIMA, Augusto César Moreira. Precedentes no Direito. São Paulo: LTr, 2001. p. 62.

${ }^{10}$ DWORKIN, Ronald. Levando os direitos a sério. São Paulo: Martins Fontes, 2002. p. 174.
} 
A jurisprudência encontra seu limite direto na lei, uma vez que, em regra, prevalece o sistema do direito escrito. Contudo, não se pode afirmar que no common law o juiz é livre para descumprir a lei. No sistema de precedentes a tradição jurídica apenas é mais flexível e leva em consideração, como dito anteriormente, uma comunidade de princípios para além do texto escrito.

No common law o juiz não possui o poder que os críticos alegam, isto porque está mais vinculado aos precedentes do que os juízes atuantes no civil law. Na realidade, quem possui um relativo poder é o grupo de juízes.

Genericamente, também é possível afirmar que no sistema do common law o direito fica engessado, uma vez que os juízes se sentem compelidos a seguir os precedentes formulados pelas cortes superiores. Todavia, os precedentes podem sim ser superados, devendo o juiz apenas partir da ideia já firmada e delimitar os motivos que o levaram a superar o precedente (overruling) ou desconsiderá-lo (distinguishing).

\subsection{Ratio decidendi e Obiter Dictum}

De forma bastante superficial, podemos delimitar a ratio decidendi ${ }^{11}$ (holding) como os fundamentos jurídicos que sustentam uma decisão judicial. Ou seja, é a opção hermenêutica adotada pelo juiz, baseada em elementos sociológicos, históricos e até psicológicos, sem a qual a decisão não teria sido proferida daquela determinada forma.

No precedente obrigatório, inclusive, pode haver vários holdings que servirão de fundamento (vinculação) para futuras decisões judiciais.

Pierluigi Chiassoni, citado na obra de Lenio Luiz Streck e Georges Abboud, afirma que é possível elencar sete conceitos cunhados pela tradição sobre ratio decidendi:

É o critério decisional, ou seja, a regra que está subjacente à decisão; é o princípio de direito adotado para definir o conteúdo da demanda; é a premissa ou a passagem lógica que se revela necessária para se alcançar a decisão do caso; é a regra ou princípio que constitui a condição necessária ou suficiente; é o principio de direito contido na decisão judicial e que é suficiente para decidir o caso concreto; é a argumentação explícita ou implícita necessária ou suficiente

\footnotetext{
11 A expressão ratio decidendi não é unívoca, sendo mais utilizada na Inglaterra, em algumas oportunidades, como sinônimo de holding, e, em outras, como correspondente à fundamentação da decisão, à razão de decidir (mesmo porque, para alguns, o holding abrange a razão de decidir). Neste trabalho, será tratada com o mesmo significado de holding.
} 
para definir o caso e, por último, é a relação entre resolução (motivada) do caso e o próprio caso, ou seja, o fato e as questões jurídicas inerentes. ${ }^{12}$

A ratio decidendi, além de possuir função de colocar-se como fundamento jurídico a solucionar casos no common law, também possui a função de evitar arbitrariedades nas decisões judiciais. ${ }^{13}$ Percebe-se, assim, que as razões de decidir ou os fundamentos da decisão importam, no common law, porque a decisão não diz respeito apenas às partes. A decisão, vista como precedente, interessa aos juízes ${ }^{14}$ e aos jurisdicionados/cidadãos.

Há também a obiter dictum que nos remete à parte da decisão considerada "dispensável". ${ }^{15}$ São argumentos acessórios que acompanham as razões de decidir (ratio decidendi).

A importância de se delimitar a distinção entre ratio e obter dictum é fundamental no sistema de precedentes, uma vez que é necessário estabelecer o precedente jurídico que será fundamental para a solução de novos casos. Inclusive, a doutrina destaca a dificuldade de se definir o que é vinculante dentro do precedente.

\subsection{Overruling e Distinguishing}

Dois métodos são utilizados pelos tribunais para evitar seguir um precedente: overruling e distinguishing. Em ambas as ocasiões o juiz deve expor de forma exauriente os motivos da não aplicação do precedente.

O overruling nada mais é do que a superação do precedente. É a revogação de um precedente com o objetivo de confirmar o direito.

Para Luiz Guilherme Marinoni,

\footnotetext{
12 PIERLUIGI CHIASSONI apud STRECK, Lenio Luiz; ABBOUD, Georges. O que é isto - o precedente judicial e as súmulas vinculantes? Porto Alegre: Livraria do Advogado, 2013. p. 43.

${ }^{13}$ STRECK, Lenio Luiz; ABBOUD, Georges. $O$ que é isto - o precedente judicial e as súmulas vinculantes? Porto Alegre: Livraria do Advogado, 2013. p. 44.

14 "A ratio decidendi de um caso é qualquer regra de direito expressa ou implicitamente tratada pelo juiz como passo necessário para alcançar a sua conclusão, tendo em vista a linha de raciocínio por ele adotada, ou uma parte de sua instrução para o júri". No original: "The ratio decidendi of a case is any rule of law expressly or impliedly treated by the judge as a necessary step in reaching his conclusion, having regard to the line of reasoning adopted by him, or a necessary part of his direction to the jury". CROSS, Rupert; HARRIS, J. W. Precedent in English law. Oxford: Clarendon Press, 1991. p. 77.

${ }^{15}$ Parte da doutrina defende a ideia que em alguns casos a obter dicta trata de maneira aprofundada um ponto de direito relacionado ao julgamento; esta obter dictum que se aproxima da ratio decidendi, embora não tenha efeito obrigatório, tem efeito persuasivo bastante forte.
} 
a revogação de um precedente depende de adequada confrontação entre os requisitos básicos para o overruling - ou seja, a perda de congruência social e o surgimento de inconsistência sistêmica - e os critérios que ditam as razões para a estabilidade ou para a preservação do precedente - basicamente a confiança justificada e a prevenção contra a surpresa injusta. ${ }^{16}$

O clássico exemplo de superação de um precedente é o caso Brown x Board of Education (1954). ${ }^{17} \mathrm{Em} \mathrm{1868,} \mathrm{com} \mathrm{o} \mathrm{fim} \mathrm{da} \mathrm{Guerra} \mathrm{Civil,} \mathrm{foi} \mathrm{inserido} \mathrm{na} \mathrm{Constituição} \mathrm{norte-}$ americana, através da décima quarta Emenda, o princípio da igualdade (equal protection of the law). Todavia, os mesmos membros do Congresso que editaram a emenda, legislaram, no mesmo ano, em favor do regime de escolas segregadas.

Por essa razão, em 1896, no caso Plessy x Ferguson, a Suprema Corte decidiu que a segregação nos transportes ferroviários era compatível com o princípio da igualdade, utilizando o lema "iguais, mas separados" (equal but separate), já que essa teria sido a intenção do constituinte.

Já no caso Brown x Board of Education a Suprema Corte teve que decidir sobre a constitucionalidade da segregação racial nas escolas. Os fatos eram estes: na cidade de Topeka, no Estado do Kansas, Oliver Brown e vários outros negros tentaram matricular seus filhos em uma escola pública primária exclusiva para brancos e, consequentemente, o pedido foi negado. Em razão disso, eles entraram na Justiça alegando que tinham o direito à matrícula, já que o sistema de segregação em escola pública seria inconstitucional por ferir a décima quarta Emenda.

Com base no precedente Plessy $x$ Ferguson, as Cortes inferiores indeferiram o pedido dos autores, embora tivessem reconhecido que o sistema de segregação era prejudicial às crianças negras. Em 1954, o processo chegou à Suprema Corte, que decidiu que a política de segregação racional nas escolas comprometia o desenvolvimento educacional do grupo segregado.

Importante mencionar, por fim, que o overruling pode não ocorrer de forma expressa. Às vezes a mudança se dá de forma gradual e acompanha a evolução da sociedade. Ademais, alguns autores também dividem três espécies de overruling: overruling de precedentes

\footnotetext{
${ }^{16}$ MARINONI, Luiz Guilherme. Precedentes obrigatórios. 2. ed. São Paulo: Revista dos Tribunais, 2011. p. 393.

17 ESTADOS UNIDOS. Suprema Corte dos Estados Unidos. Brown v. Board of Education. 17 maio 1954. Disponível em: <http://caselaw.findlaw.com/us-supreme-court/347/483.html>. Acesso em: 14 set. 2017.
} 
meramente persuasivos, overruling de precedentes obrigatórios em sentido forte (formalmente vinculantes), overruling de precedentes obrigatórios em sentido frágil. ${ }^{18}$

Já o distinguishing "expressa a distinção entre casos para o efeito de se subordinar, ou não, o caso sob julgamento a um precedente". ${ }^{19}$ A distinção de um caso é fundamentalmente um problema de diferenciar a ratio decidendi da obiter dicta.

Sendo assim, pode o juiz entender que a adoção do precedente não é o ideal ao caso atual, haja vista que as ações podem evidenciar fatos distintos.

\section{OS “PRECEDENTES” NO SISTEMA JURÍDICO BRASILEIRO (STF E STJ)}

Ao colocar entre aspas a palavra precedente, busca-se demonstrar que tal sentido deve ser empregado de forma diversa no sistema jurídico brasileiro. Isto porque, conforme se verá na sequência, as decisões proferidas pelos tribunais superiores vinculam - algumas de forma obrigatória, outras não - as demais esferas do Poder Judiciário, porém, fogem completamente da verdadeira essência do stare decisis. Ademais, será exposto que o atual sistema deliberativo dos tribunais impede a efetiva recepção da teoria adotada pelo common law.

\subsection{Precedentes no Supremo Tribunal Federal}

\subsubsection{Decisão proferida no controle difuso de constitucionalidade}

Em uma leitura de qualquer manual de Direito Constitucional pode-se concluir que o controle de constitucionalidade se classifica entre difuso e concentrado.

Controle concentrado configura-se pelo exame da constitucionalidade de uma lei a ser realizado, em abstrato, por um único e, normalmente, principal órgão do Poder Judiciário. ${ }^{20}$ Quanto ao controle difuso, este se caracteriza por ser desenvolvido por todos os membros do Poder Judiciário, isto é, qualquer juiz pode apreciar a constitucionalidade da lei.

\footnotetext{
${ }^{18}$ BUSTAMANTE, Thomas da Rosa de. Teoria do precedente judicial: a justificação e a aplicação de regras jurisprudenciais. São Paulo: Noeses, 2012. p. 390-413.

${ }_{19}$ MARINONI, Luiz Guilherme. Precedentes obrigatórios. 2. ed. São Paulo: Revista dos Tribunais, 2011. p. 327.

${ }^{20}$ Ex. Ação direta de inconstitucionalidade; Ação declaratória de constitucionalidade; e Arguição de descumprimento de preceito fundamental.
} 
No controle concentrado de constitucionalidade somente as partes que estão legitimadas na Constituição Federal poderão provocar o juízo. Ademais, em regra, a decisão terá eficácia erga omnes (contra todos) e produzirá efeitos ex tunc (retroatividade). ${ }^{21}$

Ainda referente ao controle concentrado, vale informar que o STF poderá, por maioria de $2 / 3$ dos seus membros, restringir os efeitos da declaração de inconstitucionalidade ou decidir que ela só tenha eficácia a partir de seu trânsito em julgado ou de outro momento que venha a ser fixado, conforme disciplina o artigo 27 , da Lei $\mathrm{n}^{\circ} 9.868 / 99^{22}$.

Já no controle difuso de constitucionalidade, qualquer pessoa pode alegar a inconstitucionalidade da lei ou ato normativo, seja como autora ou como ré, em um processo judicial. A arguição será incidenter tantum.

Ocorre, porém, que no controle difuso a norma declarada inconstitucional somente vale para as partes litigantes. Tal validade somente será relacionada aos demais cidadãos, caso o Senado Federal, nos termos do artigo 52, X, da Constituição Federal, suspenda no todo ou em parte a execução da norma declarada inconstitucional ${ }^{23}$.

No caso concreto, a declaração do Supremo Tribunal Federal na via de controle difuso produzirá efeitos ex tunc, encerrando desde o início a relação jurídica. Observe-se, também, que no caso do Senado Federal aceitar a decisão proferida pelo STF, além do efeito erga omnes, haverá eficácia ex tunc. ${ }^{24}$

Em que pese o procedimento constitucional anteriormente mencionado, o STF, através de parte dos seus ministros, ${ }^{25}$ vem adotando o entendimento de que mesmo no controle difuso

\footnotetext{
${ }^{21}$ Redação dada pela EC $n^{\circ}$ 45/2004 ao artigo 102, § $2^{\circ}$, da Constituição Federal de 1988: “As decisões definitivas de mérito, proferidas pelo Supremo Tribunal Federal, nas ações diretas de inconstitucionalidade e nas ações declaratórias de constitucionalidade produzirão eficácia contra todos e efeito vinculante, relativamente aos demais órgãos do Poder Judiciário e à administração pública direta e indireta, nas esferas federal, estadual e municipal”. BRASIL. Constituição Federal. Diário Oficial da República Federativa do Brasil, Brasília, 5 out. 1988. Disponível em: <http://www.planalto.gov.br/ccivil_03/constituicao/constituicao.htm>. Acesso em: 14 dez. 2017.

${ }^{22}$ BRASIL. Lei $n^{\circ} 9.868$, de 10 de novembro de 1999. Dispõe sobre o processo e julgamento da ação direta de inconstitucionalidade e da ação declaratória de constitucionalidade perante o Supremo Tribunal Federal. Diário Oficial da República Federativa do Brasil, Brasília, 11 nov. 1999. Disponível em: <http://www.planalto.gov.br/Ccivil_03/Leis/L9868.htm>. Acesso em: 14 dez. 2017.

${ }^{23}$ BRASIL. Constituição Federal. Diário Oficial da República Federativa do Brasil, Brasília, 5 out. 1988. Disponível em: <http://www.planalto.gov.br/ccivil_03/constituicao/constituicao.htm>. Acesso em: 14 dez. 2017.

${ }^{24}$ Alguns doutrinadores entendem que neste caso haverá eficácia ex nunc.

25 "Considerou o relator que, em razão disso, bem como da multiplicação de decisões dotadas de eficácia geral e do advento da Lei $9.882 / 99$, alterou-se de forma radical a concepção que dominava sobre a divisão de poderes, tornando comum no sistema a decisão com eficácia geral, que era excepcional sob a EC 16/65 e a CF 67/69. Salientou serem inevitáveis, portanto, as reinterpretações dos institutos vinculados ao controle incidental de inconstitucionalidade, notadamente o da exigência da maioria absoluta para declaração de inconstitucionalidade e o da suspensão de execução da lei pelo Senado Federal. Reputou ser
} 
de constitucionalidade e sem autorização expressa do Senado Federal, poderá ser admitida eficácia vinculante erga omnes das decisões proferidas pelo Pleno. De acordo com os ministros, isto decorre de uma mutação constitucional do artigo 52, X, da Constituição Federal, e se denomina como a teoria da transcendência dos motivos determinantes. ${ }^{26}$

Referida teoria foi debatida na reclamação constitucional $n^{\circ} 4.335$, ajuizada pela Defensoria Pública da União contra o Juiz de Direito da Vara de Execuções Penais da Comarca de Rio Branco/AC. Aqui, alegava-se o descumprimento da decisão do STF no HC 82.959, no qual a Corte declarou a inconstitucionalidade do art. $2^{\circ}$, $\$ 1^{\circ}$, da Lei 8.072/1990 (Lei de crimes hediondos), que vedava a progressão de regime em casos de crimes hediondos.

Entendeu o magistrado de primeira instância que a decisão do Supremo somente teria eficácia a partir da expedição, pelo Senado Federal, da resolução suspendendo a eficácia do dispositivo de lei declarada inconstitucional, nos termos do art. 52, inciso X, da CF.

Vale mencionar que o entendimento defendido por parte dos ministros do STF também foi seguido pelo jurista Teori Albino Zavaski quando ainda atuava no Superior Tribunal de Justiça:

A inconstitucionalidade é vício que acarreta a nulidade ex tunc do ato normativo, que, por isso mesmo, é desprovido de aptidão para incidir eficazmente sobre os fatos jurídicos desde então verificados, situação que não pode deixar de ser considerada. Também não pode ser desconsiderada a decisão do STF que reconheceu a inconstitucionalidade. Embora tomada em controle difuso, é decisão de incontestável e natural vocação expansiva, com eficácia imediatamente, vinculante para os demais tribunais, inclusive o STJ (CPC, art. 481, § único: "Os órgãos fracionários dos tribunais, não se submeterão ao plenário, ou ao órgão especial, a argüição de inconstitucionalidade, quando já houver pronunciamento destes ou do plenário do STF sobre a questão"), e como força de inibir a execução de sentenças judiciais contrárias, que se tornam inexigíveis (CPC, art. 741, § único; art. 475 - L, $\S 1^{\circ}$, redação da Lei $11.232 / 05 \ldots$... . Sob esse enfoque, há idêntica força de autoridade nas decisões do STF em ação direta quanto nas proferidas em via recursal. Merece aplausos essa

\footnotetext{
legítimo entender que, atualmente, a fórmula relativa à suspensão de execução da lei pelo Senado há de ter simples efeito de publicidade, ou seja, se o STF, em sede de controle incidental, declarar, definitivamente, que a lei é inconstitucional, essa decisão terá efeitos gerais, fazendo-se a comunicação àquela Casa legislativa para que publique a decisão no Diário do Congresso. Concluiu, assim, que as decisões proferidas pelo juízo reclamado desrespeitaram a eficácia erga omnes que deve ser atribuída à decisão do STF no HC 82.959/SP Após, pediu vista o Min. Eros Grau. Rcl 4335/AC, rel. Min. Gilmar Mendes, $1^{\circ}$.2.2007. (Rcl-4335)". BRASIL. Supremo Tribunal Federal. Reclamação: Cabimento e Senado Federal no Controle da Constitucionalidade - 4. Informativo STF $\mathrm{n}^{\circ}$ 454. 1-2 fev. 2007. Disponível em: <http://www.stf.jus.br/arquivo/informativo/documento/informativo454.htm>. Acesso em: 14 dez. 2017.

26 Parte da doutrina e dos magistrados critica esta atuação ativista do Poder Judiciário ao utilizar da chamada "mutação constitucional" para afastar a própria letra da lei. Cf. PEDRON, Flávio Quinaud. Mutação constitucional na crise do positivismo jurídico: história e crítica do conceito no marco da teoria do Direito como integridade. Belo Horizonte: Arraes, 2012. p. 22.
} 
aproximação, cada vez mais evidente, do sistema de controle difuso de constitucionalidade ao do concentrado, que se generaliza em outros países $[\ldots]^{27}$

As justificativas desse novo posicionamento seriam a força normativa da Constituição, o princípio da supremacia da Constituição e a sua aplicação uniforme buscando a segurança jurídica.

Convém observar, finalmente, que a mudança de concepção a respeito da competência do Senado Federal não seria proveniente de uma reforma constitucional. A mudança surgiria através de uma "nova interpretação" - fundamentada na mutação constitucional - do STF com relação à norma do artigo 52, X, da Constituição da República.

\subsubsection{Decisão proferida no controle concentrado de constitucionalidade ${ }^{28}$}

Se o STF, através de seus membros, tem atribuído eficácia vinculante às decisões proferidas em controle difuso de constitucionalidade, evidentemente que no controle abstrato o mesmo deverá ocorrer. ${ }^{29}$

Ou seja, "não são apenas os motivos determinantes da decisão tomada em controle difuso que importam para a racionalidade do controle da constitucionalidade". ${ }^{30}$

Na reclamação constitucional $n^{\circ} 1.987$, a qual foi reafirmada pelo Plenário do Supremo Tribunal Federal na Rcl 2.363, o Ministro Gilmar Mendes argumentou que

a aplicação dos fundamentos determinantes de um leading case em hipóteses semelhantes tem-se verificado, entre nós, até mesmo no controle de constitucionalidade das leis municipais. Em um levantamento precário, pude

\footnotetext{
${ }^{27}$ BRASIL. Superior Tribunal de Justiça. Recurso Especial $n^{\circ}$ 828.106/SP. Vilar Comércio de Bebidas Ltda e Fazenda Nacional. Relator: Ministro Teori Albino Zavascki. 15 de maio de 2006. Disponível em: <https: //ww2.stj.jus.br/processo/revista/documento/mediado/?componente=ITA\&sequencial=623920\&nu m_registro=200600690920\&data=20060515\&formato=PDF>. Acesso em: 14 dez. 2017.

28 “Art. 927. Os juízes e os tribunais observarão: I - as decisões do Supremo Tribunal Federal em controle concentrado de constitucionalidade [...]."

BRASIL. Lei $\mathrm{n}^{\circ} 13.105$, de 16 de março de 2015. Código de Processo Civil. Diário Oficial da República Federativa do Brasil, Brasília, 17 mar. 2015. Disponível em: <http://www.planalto.gov.br/ccivil_03/_ato2015-2018/2015/lei/l13105.htm>. Acesso em: 14 dez. 2017.

29 "É necessário esclarecer que a ratio decidendi das decisões proferidas em sede de ação direta de inconstitucionalidade têm, por exemplo, valor precedental diante de caso em que se questiona lei estadual que possui o mesmo teor da lei estadual já declarada inconstitucional. Nessa perspectiva, admite-se que os fundamentos determinantes ou a ratio decidendi da decisão proferida na ação de inconstitucionalidade têm eficácia vinculante". MARINONI, Luiz Guilherme. Julgamento nas cortes supremas: precedente e decisão do recurso diante do novo CPC. São Paulo: Revista dos Tribunais, 2015. p. 21.

${ }^{30}$ MARINONI, Luiz Guilherme. Precedentes obrigatórios, p. 469.
} 
constatar que muitos juízes desta Corte têm, constantemente, aplicado em caso de declaração de inconstitucionalidade o precedente fixado a situações idênticas reproduzidas em leis de outros municípios. Tendo em vista o disposto no caput e $\S 1^{\circ}$ - A do art. 557 do CPC (1973), que reza sobre a possibilidade de o relator julgar monocraticamente recurso interposto contra decisão que esteja em confronto com súmula ou jurisprudência dominante do Supremo Tribunal Federal, os membros desta Corte vêm aplicando tese fixada em precedentes onde se discutiu a inconstitucionalidade de lei, em sede de controle difuso, emanada por ente federativo diverso daquele prolator da lei objeto do recurso extraordinário sob exame. (...). Não há razão, pois, para deixar de reconhecer o efeito vinculante da decisão proferida na ADIn. Nesses termos, meu voto é no sentido da procedência da presente reclamação. ${ }^{31}$

Insta ressalvar, entretanto, que o tom adotado pelo ministro Gilmar Mendes não é aceito pacificamente no STF. Muito ainda se discute com relação à eficácia transcendente dos motivos determinantes, sobretudo no momento em que surge um novo Código de Processo Civil que reconhece explicitamente que a tese afirmada pela decisão proferida em controle concentrado de constitucionalidade produz efeitos vinculantes e que seu desrespeito possibilita a propositura de reclamação.

\subsubsection{A repercussão geral}

Para uma melhor visualização acerca do tema, pode-se afirmar que

a repercussão geral é um instrumento processual inserido na Constituição Federal de 1988, por meio da Emenda Constitucional 45, conhecida como a 'Reforma do Judiciário'. O objetivo desta ferramenta é possibilitar que o Supremo Tribunal Federal, por meio do Plenário, selecione os Recursos Extraordinários que irá analisar, de acordo com critérios de relevância jurídica, política, social ou econômica. ${ }^{32}$

O Código de Processo Civil/2015 discrimina no art. 1.035, caput, que "o Supremo Tribunal Federal, em decisão irrecorrível, não conhecerá do recurso extraordinário quando a

\footnotetext{
${ }^{31}$ BRASIL. Supremo Tribunal Federal. Reclamação 2.363. Município de Capitão Poço, Presidente do Tribunal Regional do Trabalho da $8^{\mathrm{a}}$ Região e Iraneide Galdino Moreira e outro. Relator: Ministro Gilmar Mendes. 1 de abril de 2005. Disponível <http://redir.stf.jus.br/paginadorpub/paginador.jsp?docTP=AC\&doclD=365588>. Acesso em: 14 dez. 2017. 32 BRASIL. Supremo Tribunal Federal. Constitucionalidade do instituto da repercussão geral é questionada no $\quad 19$ japremo. 2010. Disponível em: <http://www.stf.jus.br/portal/cms/verNoticiaDetalhe.asp?idConteudo=118645>. Acesso em: $14 \mathrm{dez}$. 2017.
} 
questão constitucional nela versada não tiver repercussão geral, nos termos deste artigo"33. Ainda, delimita no art. $1.035, \S 3^{\circ}$, que “haverá repercussão geral sempre que o recurso impugnar acórdão que: contrarie súmula ou jurisprudência dominante do Supremo Tribunal Federal; tenha reconhecido a inconstitucionalidade de tratado ou de lei federal, nos termos do art. 97 da Constituição Federal”34.

Sendo assim, nos parece óbvio que toda decisão proferida através de recurso extraordinário deve possuir efeito vinculante, sobretudo porque haverá relevância jurídica, política, social ou econômica (art. 1.035, § $1^{\circ}$ ).

Ademais, de acordo com o art. 1.035, § $8^{\circ}$, do CPC/15, “negada a repercussão geral, o presidente ou o vice-presidente do tribunal de origem negará seguimento aos recursos extraordinários sobrestados na origem que versem sobre matéria idêntica”35.

A dúvida que nasce no instituto em análise diz respeito à superação das decisões do STF, isto é, como reformar/revisar um "precedente", o qual, em momento histórico diverso, colacionou a inexistência da repercussão geral? Se os tribunais devem rejeitar liminarmente os recursos que possuem temas sem repercussão geral, para quem se deve pleitear o overrruling?

O legislador acabou com a omissão do CPC/73 e delimitou no art. 1.030, § 2 , do CPC/15 que a parte que considerar equivocada a aplicação da repercussão geral, inclusive nas ações repetitivas, poderá interpor agravo interno perante o tribunal de origem. ${ }^{36}$

0 problema na questão anteriormente aventada é que o jurisdicionado fica impedido ${ }^{37}$, em caso de improvimento do agravo interno, de ver suas razões recursais analisadas pelo

33 BRASIL. Lei $n^{\circ}$ 13.105, de 16 de março de 2015. Código de Processo Civil. Diário Oficial da República Federativa do Brasil, Brasília, 17 mar. 2015. Disponível em: <http://www.planalto.gov.br/ccivil_03/_ato2015-2018/2015/lei/l13105.htm>. Acesso em: 14 dez. 2017.

${ }^{34}$ BRASIL. Lei $\mathrm{n}^{\circ} 13.105$, de 16 de março de 2015. Código de Processo Civil. Diário Oficial da República Federativa do Brasil, Brasília, 17 mar. 2015. Disponível em: <http://www.planalto.gov.br/ccivil_03/_ato2015-2018/2015/lei/l13105.htm>. Acesso em: 14 dez. 2017.

35 BRASIL. Lei $\mathrm{n}^{\circ} 13.105$, de 16 de março de 2015. Código de Processo Civil. Diário Oficial da República Federativa do Brasil, Brasília, 17 mar. 2015. Disponível em: <http://www.planalto.gov.br/ccivil_03/_ato2015-2018/2015/lei/l13105.htm>. Acesso em: 14 dez. 2017. ${ }^{36}$ Ainda que a legislação anterior fosse omissa, o STF já acolhia a interposição do agravo interno.

BRASIL. Supremo Tribunal Federal. Questão de ordem em Agravo de Instrumento 760.358-SE. Unão e Jacileide Dantas dos Santos. Relator: Ministro Gilmar Mendes. 19 de novembro de 2009. Disponível em: <http://redir.stf.jus.br/paginadorpub/paginador.jsp?docTP=AC\&doclD=608471 >. Acesso em: 14 dez. 2017. BRASIL. Supremo Tribunal Federal. Reclamação 7.569-SP. Município de São Paulo, Presidente do Tribunal de Justiça do Estado de São Paulo e Luiz Antônio Mariano Lozano e outro. Relatora: Ministra Ellen Gracie. 19 de novembro de 2009.2 Disponível <http://redir.stf.jus.br/paginadorpub/paginador.jsp?docTP=AC\&doclD=606662>. Acesso em: 14 dez. 2017. 37 "Art. 1.042. Cabe agravo contra decisão do presidente ou do vice-presidente do tribunal recorrido que inadmitir recurso extraordinário ou recurso especial, salvo quando fundada na aplicação de entendimento firmado em regime de repercussão geral ou em julgamento de recursos repetitivos." (grifo nosso) 
Supremo Tribunal Federal que é quem, em tese, possui legitimidade de alterar seus próprios precedentes. Tal atitude não se coaduna com os ensinamentos do verdadeiro precedente judicial (stare decisis).

\subsubsection{Súmulas ${ }^{38}$}

As chamadas súmulas são a cristalização de entendimentos jurisprudenciais que predominam nos Tribunais em certo espaço de tempo. A palavra quer indicar as decisões reiteradamente proferidas em determinado sentido pelos Tribunais.

0 grande cerne da questão é que, infelizmente, os prolatores das súmulas não se preocupam em garantir a coerência e/ou previsibilidade. Inclusive, é costumeiro o descumprimento dos próprios tribunais superiores com relação às suas súmulas. ${ }^{39}$

Ademais, a formatação dos enunciados não possui uma lógica e, principalmente, não consigna os fundamentos essenciais das decisões que geraram a súmula. ${ }^{40}$ BRASIL. Lei $\mathrm{n}^{\circ}$ 13.105, de 16 de março de 2015. Código de Processo Civil. Diário Oficial da República
Federativa do Brasil, Brasília, 17 mar. 2015. Disponível em: <http://www.planalto.gov.br/ccivil_03/_ato2015-2018/2015/lei/l13105.htm>. Acesso em: 14 dez. 2017.

38 "Art. 927. Os juízes e os tribunais observarão: IV - os enunciados das súmulas do Supremo Tribunal Federal em matéria constitucional e do Superior Tribunal de Justiça em matéria infraconstitucional (...)." BRASIL. Lei ${ }^{\circ} 13.105$, de 16 de março de 2015. Código de Processo Civil. Diário Oficial da República Federativa do Brasil, Brasília, 17 mar. 2015. Disponível em: <http://www.planalto.gov.br/ccivil_03/_ato2015-2018/2015/lei/l13105.htm>. Acesso em: 14 dez. 2017.

${ }^{39}$ Exemplo: A súmula 634 do STF, que se encontra obsoleta em virtude do art. 1.029 , § $5^{\circ}$, do $\mathrm{CPC} / 15$, afirma que "não compete ao Supremo Tribunal Federal conceder medida cautelar para dar efeito suspensivo a recurso extraordinário que ainda não foi objeto de juízo de admissibilidade na origem". BRASIL. Supremo Tribunal Federal. Súmula 634. 13 out. 2003. Disponível em: <http://www.stf.jus.br/portal/jurisprudencia/menuSumarioSumulas.asp?sumula=2023>. Acesso em: 14 dez. 2017.

Todavia, os ministros do STF sempre admitiram a ação cautelar, ainda que pendente o juízo de admissibilidade no tribunal de origem ou mesmo que não admitido o recurso extraordinário e interposto agravo de instrumento (v. BRASIL. Supremo Tribunal Federal. Questão de ordem em medida cautelar em ação cautelar 1.549 - RO. Companhia de Águas e Esgotos de Rondônia - CAERD e Município de Cerejeiras. Relator: Ministro Celso de Mello. 13 de fevereiro de 2007. Disponível em: <http: / /redir.stf.jus.br/paginadorpub/paginador.jsp?docTP=AC\&doclD=443436>. Acesso em: 14 dez. 2017; BRASIL. Supremo Tribunal Federal. Ação Cautelar 1.550-2-RO. Companhia de Águas e Esgotos de Rondônia - CAERD e Município de Guajará Mirim. Relator: Ministro Gilmar Mendes. 6 de fevereiro de 2007. Disponível em: <http://redir.stf.jus.br/paginadorpub/paginador.jsp?docTP=AC\&doclD=456054>. Acesso em: 14 dez. 2017.)

40 “A súmula não se preocupa com fundamentos, mas apenas em expressar um enunciado, que é um simples resultado interpretativo. Um mero enunciado ou resultado interpretativo jamais será capaz de fornecer aos juízes dos casos futuros as razões da decisão. Lembre-se que a súmula deriva da reafirmação de resultados iguais e não de fundamentos iguais. Na verdade, mesmo que se pensasse numa 'súmula dos fundamentos' - que, assim, não seria um enunciado, mas um longo arrazoado -, isso na prática seria impossível, pois as razões são inseparáveis da situação concreta". MARINONI, Luiz Guilherme. Julgamento 
Enquanto o precedente judicial, nos moldes do common law, delimita toda a racionalidade jurídica (ratio), a súmula apenas se presta a mencionar um resumo do dispositivo.

Em suma, o repertório de súmulas se transformou num mero 'guia de interpretação', sem qualquer correspondência com os casos de onde afloraram e com a própria prática do direito jurisprudencial. Transformou-se, melhor dizendo, num 'guia de interpretação estático' e sem qualquer compromisso com o desenvolvimento do direito e com a realização da justiça nos casos concretos. ${ }^{41}$

Patrícia Perrone Campos Mello é ainda mais precisa ao afirmar que o texto escrito das súmulas:

[...] é uma barreira a novas interpretações reconformadoras dos precedentes; além disso, a formulação do holding pelo próprio tribunal, sem a participação das cortes vinculadas em sua gênese, afasta de tal processo esta importante instância crítica, que lida, em seu dia-a-dia, com uma riqueza fática maior, e que poderia contribuir na definição da generalidade da norma. ${ }^{42}$

\subsubsection{Súmulas vinculantes}

A Emenda Constitucional $n^{\circ} 45 / 2004$ incluiu no texto constitucional o art. 103-A, que prevê a possibilidade de o STF editar súmula com caráter obrigatório e vinculante para todo o Poder Judiciário, e ainda para a Administração Pública direta e indireta.

Destarte, restou estabelecido que

- Supremo Tribunal Federal poderá, de ofício ou por provocação, mediante decisão de dois terços dos seus membros, após reiteradas decisões sobre matéria constitucional, aprovar súmula que, a partir de sua publicação na imprensa oficial, terá efeito vinculante em relação aos demais órgãos do Poder Judiciário e à administração pública direta e indireta, as esferas federal, estadual e municipal, bem como proceder à sua revisão ou cancelamento, na forma estabelecida em lei. ${ }^{43}$

Para Rodolfo de Camargo Mancuso,

nas cortes supremas: precedente e decisão do recurso diante do novo CPC. São Paulo: Revista dos Tribunais, 2015. p. 26.

${ }^{41}$ MARINONI, Luiz Guilherme. Precedentes obrigatórios. 2. ed. São Paulo: Revista dos Tribunais, 2011. P. 485.

42 MELLO, Patrícia Perrone Campos. Precedentes - O desenvolvimento judicial do direito no constitucionalismo contemporâneo. Rio de Janeiro: Renovar, 2008. p. 147-148.

${ }^{43}$ BRASIL. Constituição Federal. Diário Oficial da República Federativa do Brasil, Brasília, 5 out. 1988. Disponível em: <http://www.planalto.gov.br/ccivil_03/constituicao/constituicao.htm>. Acesso em: 14 dez. 2017. 
a formulação de uma súmula vinculativa, justamente por seu efeito erga omnes, em face do Estado e dos jurisdicionados, exige do tribunal um cuidado extremo, seja no que concerne à própria deliberação quanto à sua emissão, seja quanto à sua redação, tudo para prevenir que ela, ao invés de concorrer para a melhoria da resposta judiciária, não venha a se constituir em mais um óbice. ${ }^{44}$

Inobstante a tentativa de melhoria no Judiciário, percebe-se que a súmula vinculante, na realidade, veio a "engessar" o Direito muito mais do que ocorre no instituto do stare decisis. Primeiro porque poucos são os legitimados a pleitear a revogação dos enunciados; e segundo porque os enunciados são formulados sem qualquer critério formal e não delimitam a racionalidade jurídica das decisões que serviram de base para sua formulação.

$\mathrm{Na}$ realidade, se torna necessário um novo método para formulação das súmulas vinculantes, as quais não possuem a devida fundamentação e, por vezes, são contraditórias e obscuras. Um forte exemplo é a súmula vinculante $n^{\circ} 03$, cujo teor ${ }^{45}$ deu a entender que era possível que nos casos de apreciação da legalidade do ato de concessão inicial de aposentadoria, reforma e pensão não seria necessário observar o contraditório e a ampla defesa.

Outro exemplo diz respeito à súmula vinculante $\mathrm{n}^{\circ} 13$, a qual foi prolatada através de um caso único. Ou seja, não houve seguimento ao que está claramente disposto na Constituição Federal (“o Supremo Tribunal Federal poderá, de ofício ou por provocação, mediante decisão de dois terços dos seus membros, após reiteradas decisões $(\ldots)$ "46).

Com efeito, podemos afirmar que os magistrados brasileiros ainda não estão prontos para adotar o sistema de precedentes, o qual foi aperfeiçoado por dezenas de anos no sistema anglo-americano.

\subsubsection{Recursos repetitivos}

Estabelece o art. 1.036 do Código de Processo Civil/2015 que:

\footnotetext{
${ }^{44}$ MANCUSO, Rodolfo de Camargo. Divergência jurisprudencial e súmula vinculante. 4. ed. São Paulo: Revista dos Tribunais, 2010. p. 362.

45 "Nos processos perante o tribunal de contas da união asseguram-se o contraditório e a ampla defesa quando da decisão puder resultar anulação ou revogação de ato administrativo que beneficie o interessado, excetuada a apreciação da legalidade do ato de concessão inicial de aposentadoria, reforma e pensão." BRASIL. Supremo Tribunal Federal. Súmula Vinculante 3. 6 jun. 2007. Disponível em: <http://www.stf.jus.br/portal/jurisprudencia/menuSumario.asp?sumula=1191>. Acesso em: 14 dez. 2017. ${ }^{46}$ BRASIL. Constituição Federal. Diário Oficial da República Federativa do Brasil, Brasília, 5 out. 1988. Disponível em: <http://www.planalto.gov.br/ccivil_03/constituicao/constituicao.htm>. Acesso em: 14 dez. 2017.
} 
Sempre que houver multiplicidade de recursos extraordinários ou especiais com fundamento em idêntica questão de direito, haverá afetação para julgamento de acordo com as disposições desta Subseção, observado o disposto no Regimento Interno do Supremo Tribunal Federal e no do Superior Tribunal de Justiça. ${ }^{47}$

A primeira crítica diz respeito ao método de escolha do recurso extraordinário que servirá de paradigma para os demais casos, isto é, qual o critério adotado pelo STF na subida do recurso?

Não seria mais adequado deixar o primeiro caso chegar ao tribunal superior para que, a partir da sua resolução, ficassem os tribunais e juízos estaduais e federais obrigados em face do precedente então formado?

Outra crítica deve ser feita com relação ao impedimento na subida de recursos com o desiderato de reformar as decisões proferidas em recursos repetitivos. Se os tribunais devem rejeitar liminarmente os recursos que possuem temas já julgados em recurso repetitivo, para quem se deve pleitear o overrruling?

O legislador trouxe um meio recursal cabível (art. 1.030, § $2^{\circ}, \mathrm{CPC} / 15$ ), mas continuou impedindo o jurisdicionado de ver suas razões recursais analisadas pelo próprio Supremo Tribunal Federal que é quem, em tese, possui legitimidade de alterar seus precedentes.

\subsubsection{Incidente de assunção de competência}

O artigo 947 do CPC/15 determina que "é admissível a assunção de competência quando o julgamento de recurso, de remessa necessária ou de processo de competência originária envolver relevante questão de direito, com grande repercussão social, sem repetição em múltiplos processos"48. Já o parágrafo terceiro do referido artigo delimita que “o acórdão proferido em assunção de competência vinculará todos os juízes e órgãos fracionários, exceto se houver revisão de tese" ${ }^{49}$.

\footnotetext{
${ }^{47}$ BRASIL. Lei $n^{\circ} 13.105$, de 16 de março de 2015. Código de Processo Civil. Diário Oficial da República Federativa do Brasil, Brasília, 17 mar. 2015. Disponível em: <http://www.planalto.gov.br/ccivil_03/_ato2015-2018/2015/lei/l13105.htm>. Acesso em: 14 dez. 2017. ${ }^{48}$ BRASIL. Lei ${ }^{\circ} 13.105$, de 16 de março de 2015. Código de Processo Civil. Diário Oficial da República Federativa do Brasil, Brasília, 17 mar. 2015. Disponível em: <http://www.planalto.gov.br/ccivil_03/_ato2015-2018/2015/lei/l13105.htm>. Acesso em: 14 dez. 2017. ${ }^{49}$ BRASIL. Lei $\mathrm{n}^{\circ}$ 13.105, de 16 de março de 2015. Código de Processo Civil. Diário Oficial da República Federativa do Brasil, Brasília, 17 mar. 2015. Disponível em: <http://www.planalto.gov.br/ccivil_03/_ato2015-2018/2015/lei//13105.htm>. Acesso em: 14 dez. 2017.
} 


\subsubsection{Decisões de plenário ou de órgão especial}

Buscando uma coerência dentro dos próprios tribunais, o legislador instituiu no art. 927, inciso $\mathrm{V}$, do CPC/15 que os juízes e tribunais deverão observar a orientação do plenário ou do órgão especial aos quais estiverem vinculados.

\subsection{Precedentes no Superior Tribunal de Justiça}

Criado através da Constituição Federal de 1988 e instalado no ano seguinte, o Superior Tribunal de Justiça, conforme é cediço, tem a nobre missão de uniformizar a interpretação das leis federais em todo o país, seguindo os princípios constitucionais e a garantia e defesa do Estado de Direito. Já a formulação de seus “precedentes” se assemelha, em muito, ao que fora descrito em tópicos anteriores.

\subsubsection{Recursos repetitivos, súmulas e incidente de assunção de competência}

O julgamento de recursos repetitivos no STJ possui fundamento nos mesmos preceitos legais dos recursos em trâmite no STF. Ou seja, as mesmas críticas formuladas no tópico 3.1.6 merecem ser destacadas ao presente tópico.

No que tange à impossibilidade de recurso ao próprio tribunal superior para eventual reforma (overrruling) da decisão proferida em recurso repetitivo, vale destacar o voto proferido pelo até então ministro do STJ - hoje ministro do Supremo Tribunal Federal - Teori Albino Zavascki no agravo de instrumento $n^{\circ} 1.154 .599 /$ SP. Na época, ainda em vigor o CPC/73, a maioria dos ministros entendeu que o único recurso cabível contra a decisão do presidente do tribunal de origem que negava seguimento ao recurso especial com base no art. 543-C seria o agravo interno. Já o ministro Teori Zavascki foi o único a votar contra a decisão proferida no recurso. Na visão do ministro, a decisão instituiu um requisito negativo de admissibilidade de recurso especial não contemplado na Constituição, fonte normativa primária desta matéria, nem previsto na lei processual ${ }^{50}$.

\footnotetext{
${ }^{50}$ BRASIL. Superior Tribunal de Justiça. Questão de ordem no agravo de instrumento $n^{\circ}$ 1.154.599-SP. Cosan S/A Indústria e Comércio e outros, e Fazenda Nacional. Relator: Ministro Cesar Asfor Rocha. 16 de fevereiro de 2011. Disponível em: <https: / / ww2.stj.jus.br/processo/revista/documento/mediado/?componente=ITA\&tsequencial=937926\&nu

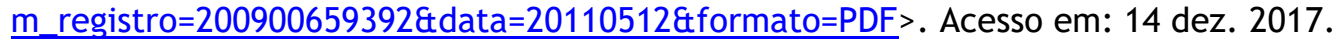


Zavascki argumentou que se negando acesso ao STJ, em casos tais, o que se faz, na prática, "é conferir aos precedentes julgados pelo regime do art. 543-C (CPC/73) não apenas um efeito vinculante ultra partes, mas também um caráter de absoluta imutabilidade, eis que não subsistiria, no sistema processual, outro meio adequado para provocar eventual revisão do julgado" 51 .

Mais adiante, o julgador discorreu que

essa deficiência não seria compatível com o nosso sistema, nem com qualquer outro sistema de direito. Mesmo os sistemas que cultuam rigorosamente a força vinculante dos precedentes judiciais admitem iniciativas dos jurisdicionados tendentes a modificar a orientação anterior, especialmente em face de novos fundamentos jurídicos ou de novas circunstâncias de fato. ${ }^{52}$

Em tempo, ao tratar sobre a técnica de solução de recursos repetitivos Marinoni afirma que

a diferença entre sobrestar processos à espera de precedente e impor precedente a processo em normal desenvolvimento está em que, no último caso, o exercício do direito de ação não é obstaculizado - que, esclareça-se, engloba o direito de recorrer e argumentar para obter a tutela jurisdicional do direito. ${ }^{53}$

Já os enunciados das súmulas formuladas pelo STJ e os acórdãos proferidos em incidente de assunção de competência devem ser observados pelos juízes e tribunais, nos moldes do que determina o art. 927, incisos III e IV, do CPC/15.

\subsubsection{Relevância da questão federal}

Em 23 de agosto de 2012 foi proposto na Câmara dos Deputados um adendo ao art. 105 da Constituição Federal, a fim de atribuir um novo requisito de admissibilidade ao recurso

\footnotetext{
${ }^{51}$ BRASIL. Superior Tribunal de Justiça. Questão de ordem no agravo de instrumento $n^{\circ}$ 1.154.599-SP. Cosan S/A Indústria e Comércio e outros, e Fazenda Nacional. Relator: Ministro Cesar Asfor Rocha. 16 de fevereiro de 2011. Disponível em: <https: / / ww2.stj.jus.br/processo/revista/documento/mediado/?componente=ITA\&sequencial=937926\&nu m_registro=200900659392\&data=20110512\&formato=PDF>. Acesso em: 14 dez. 2017.

52 BRASIL. Superior Tribunal de Justiça. Questão de ordem no agravo de instrumento $n^{\circ} 1.154 .599$-SP. Cosan S/A Indústria e Comércio e outros, e Fazenda Nacional. Relator: Ministro Cesar Asfor Rocha. 16 de fevereiro de 2011.2 Disponível em: <https: //ww2.stj.jus.br/processo/revista/documento/mediado/?componente=ITA\&sequencial=937926\&nu m_registro=200900659392\&data=20110512\&formato=PDF >. Acesso em: 14 dez. 2017.

${ }_{53}$ MARINONI, Luiz Guilherme. Precedentes obrigatórios. 2. ed. São Paulo: Revista dos Tribunais, 2011. p. 499.
} 
especial no âmbito do STJ. Com numeração 209/2012, a PEC foi amplamente defendida pelos ministros, que afirmaram estar recebendo um número expressivo de recursos com matérias de baixa importância e de cunho estritamente pessoal, isto é, sem relevância jurídica, política, econômica ou social.

Já no corrente ano (2017), sob a numeração 10/2017, a Proposta de Emenda à Constituição foi aprovada na Comissão de Constituição e Justiça do Senado Federal e encaminhada ao Plenário da Casa. No dia 09 de agosto houve uma Emenda de Plenário, ${ }^{54}$ com o consequente retorno da matéria à CCJ.

\section{PENSAMENTOS CRÍTICOS E PROPOSTAS DE REGULAMENTAÇÃO DOS PRECEDENTES}

O equívoco dos profissionais do direito no Brasil é confundir o termo jurisprudência com o termo precedente. Isto faz com que os próprios julgadores deixem de estudar o sistema do common law para se voltar única e exclusivamente para a aplicação de normas e ementas. Aliás, conforme exposto em momento anterior, a ideia de precedente é muito mais complexa do que afirmam grande parte das pessoas e de forma alguma se assemelha às súmulas vinculantes e aos recursos repetitivos. 0 "sistema de precedentes" no Brasil é, na realidade, uma ficção. Há um conjunto de provimentos vinculantes; nada mais que isso.

Basta verificar em qualquer site de busca para que se chegue à conclusão de que os mais variados tribunais emitem decisões totalmente divergentes sobre um mesmo assunto. Isto se dá, principalmente, pela falta de conhecimento de como se implantar os precedentes. Necessário, antes de qualquer coisa, que os julgadores se voltem para a qualidade/fundamentação das decisões.

Referida qualidade surge no momento em que a decisão judicial possui integridade e coerência. Em Ronald Dworkin, coerência e integridade são elementos que formam a igualdade.

\footnotetext{
54 “Art. $1^{\circ}$ O dispositivo da PEC $n^{\circ} 10$, de 2017 , que inclui o $\$ 1^{\circ}$ e renumera o $\$ 2^{\circ}$ do art. 105 , da Constituição Federal, fica acrescido do seguinte parágrafo: Art. 105 (...). $\$ 3^{\circ}$. Presume-se a relevância referida no $\$ 1^{\circ}$ deste artigo sempre que o valor da causa for igual ou superior a 150 (cento e cinquenta) vezes o valor do salário-mínimo vigente à data da propositura da ação, quando puder resultar, do julgamento da causa, a inelegibilidade do réu, em ação penal, e na hipótese de julgamento de casos repetitivos (NR)." BRASIL. Senado Federal. Emenda apresentada pelo Senador Edison Lobão à PEC $\mathbf{n}^{\circ}$ 10/2017. 2017. Disponível em: <http://legis.senado.leg.br/sdleggetter/documento?dm=6456125\&disposition=inline>. Acesso em: $14 \mathrm{dez} .2017$.
} 
Coerência liga-se à consistência lógica que o julgamento de casos semelhantes deve guardar entre si. Já a integridade é a exigência de que os juízes construam seus argumentos de forma integrada ao direito, em uma efetiva perspectiva de ajuste de substância. ${ }^{55}$

Parece lógico, mas o julgador não está autorizado a julgar a partir de ementas e julgados embalados para presente. Os efeitos mágicos de produção em série e veloz contracenam com o descompromisso, a ausência de responsabilidade do sujeito que assina. ${ }^{56}$

$\mathrm{Na}$ visão de Luiz Guilherme Marinoni isto ocorre, pois o modelo de julgamento das cortes supremas ainda é o das cortes de correção, em que importava apenas o resultado ou a parte dispositiva da decisão. Esse problema, inclusive, aponta para a necessidade de o julgamento colegiado ser conformado em direção de uma nova realidade. ${ }^{57}$ Ou seja, percebe-se que o modelo atual de deliberação no Supremo Tribunal Federal e no Superior Tribunal de Justiça impede a recepção da teoria dos precedentes.

A pergunta a ser feita é: as decisões tomadas pelo STJ e STF realmente possuem eficácia perante os demais órgãos do Poder Judiciário? Com propriedade podemos afirmar que a grande maioria das decisões, infelizmente, não possui eficácia perante os tribunais locais e os juízes de primeiro grau.

Falta coerência aos ministros no momento de prolatar decisões que, em muitas vezes, são base para milhares de casos futuros. Um simples exemplo é o julgamento da ADPF/54 que admitiu a interrupção de gravidez em casos de fetos anencéfalos.

Apesar da maioria dos ministros acolher a tese principal, todos os votos possuem motivos determinantes diversos. Alguns citam questões jurídicas e sociais, outros questões religiosas, enquanto outros citam questões pessoais ou partidárias.

Em um futuro próximo, quando se discutir de forma aberta a possibilidade de aborto, qual voto prolatado na ADPF/54 servirá de base para a decisão final? 0 motivo determinante (ratio decidendi) do voto de um ministro se sobrepõe ao do outro?

\footnotetext{
${ }^{55}$ DWORKIN, Ronald. Levando os direitos a sério. São Paulo: Martins Fontes, 2002. p. 137-139.

${ }^{56}$ Como referência, vale destacar o estudo de pesquisadores da Escola de Direito da Fundação Getúlio Vargas (FGV), que utilizou como base dados do projeto Supremo em Números. O levantamento analisou cerca de 120 mil decisões monocráticas de 2011 a 2013. Ao final, foi demonstrado que os ministros do STF recorrem à técnica do "copia e cola" em uma a cada três de suas decisões individuais. MAGRO, Maíra. Estudo aponta textos idênticos em decisões do STF. Valor, Brasília, 12 fev. 2016. Disponível em: <http:// www.valor.com.br/legislacao/4432396/estudo-aponta-textos-identicos-em-decisoes-do-stf > Acesso em: 14 dez. 2017.

57 "As Cortes Supremas, na generalidade dos sistemas de civil law, foram concebidas para corrigir - seja mediante cassação ou revisão - a interpretação da lei”. MARINONI, Luiz Guilherme. Julgamento nas cortes supremas: precedente e decisão do recurso diante do novo CPC. São Paulo: Revista dos Tribunais, 2015. p. 14-17.
} 
Outros tantos exemplos podem ser suscitados para demonstrar a falta de integridade $\mathrm{e}$ coerência nos tribunais superiores, em especial o julgamento das Ações Declaratórias de Constitucionalidade (ADCs) $n^{\circ} 43$ e 44, que tratam da possibilidade de execução da pena após condenação em segunda instância.

Percebe-se claramente que o STF e demais tribunais superiores não decidem como instituição, isto é, decidem com os argumentos de seus ministros/desembargadores, em uma soma de opiniões. Mesmo em decisões consensuais, percebe-se a ausência de uma ratio decidendi da Corte. ${ }^{58}$

É dever tanto do STJ quanto do STF reunir seus ministros em cada julgamento, a fim de discutir a uniformização da jurisprudência, sendo que todos os votos devem possuir os mesmos motivos determinantes, ou ainda, devem seguir o que Dworkin sugere de "romance em cadeia". $\mathrm{Na}$ realidade, como ocorre na Suprema Corte Norte-Americana, o ideal seria um único voto ser prolatado pelos ministros - ainda que haja divergência -, com o entendimento da maioria. ${ }^{59}$ Ademais, o relatório deveria ser o mais completo possível, mormente porque é através dele que a sociedade verifica a situação fática em discussão.

Vale considerar o comentário do ministro Gilmar Mendes no julgamento da proposta de súmula vinculante $n^{\circ} 57$, quando tratou da publicação de tese de repercussão geral: “por mais que a gente possa dizer 'ah, o fundamento determinante, a ratio decidendi deve vincular', mas

\footnotetext{
${ }^{58} \mathrm{Um}$ levantamento preliminar, mas não exaustivo, de problemas, como hipóteses de trabalho de pesquisa empírica, está apresentado em: VALE, André Rufino do. A deliberação no Supremo Tribunal Federal: ensaio sobre alguns problemas e perspectivas de análise teórica. In: FELLET, Andre; NOVELINO, Marcelo (org.). Constitucionalismo e Democracia. Salvador: Juspodivm, 2013, p. 329-348.

${ }_{59}$ Nos primeiros anos de funcionamento (entre os anos de 1793 e 1800), seguindo o costume judicial inglês, a Suprema Corte norte-americana anunciava suas decisões através das seriatim opinions de seus membros. Cada Justice pronunciava seu voto individualmente e o conjunto de todas as opiniões expostas 'em série' era assim apresentado ao público. Quando John Marshall se tornou Chief Justice, a Corte passou a adotar a prática de anunciar seus julgamentos em uma single opinion, que dessa forma passava a representar a opinião expressada pela maioria de seus membros. A partir de 1801, os Justices deixaram paulatinamente o costume de proclamar individualmente seus votos e passaram a estar mais comprometidos com a representação da unidade institucional da Corte, através da construção colegiada de uma única decisão, a opinion of the Court, dotada de uma única ratio decidendi. A redação seria então incumbida ao Chief Justice, que no caso era Marshall, mas o texto deveria expressar, em vez de sua posição pessoal, a opinião do colegiado de juízes, o qual teria que falar em uma só voz (speak in one voice). Essa inovação na prática deliberativa dos Justices demonstrou-se crucial para a afirmação da Suprema Corte como unidade institucional em face dos demais Poderes, num contexto político conturbado que marcou os primórdios da república norte-americana, e foi reconhecida posteriormente como um dos grandes feitos da histórica carreira de Marshall. Cf. ZOBELL, Karl M. Division of Opinion in the Supreme Court: a history of judicial disintegration. In: Cornell Law Quaterly Review, v. 44, p. 186-214, 1959.
} 
nós temos essa dificuldade. Quer dizer, de fato, o que é fundamento determinante? Especialmente diante da nossa técnica de julgamentos de votos autônomos"60.

Retornando à perspectiva do "romance em cadeia" - onde cada julgador deve agir como se estivesse escrevendo o capítulo de um romance, devendo para tanto partir do capítulo anterior, para poder avançar - cada novo juiz deve ler tudo o que outros juízes escreveram no passado, não só para descobrir o que disseram, mas também para chegar a uma opinião sobre o que os juízes fizeram coletivamente. Além disso, as novas decisões, assim como o romance em cadeia, devem ser construídas com base em princípios e não em políticas. ${ }^{61}$

A publicidade também deveria ser reduzida nas sessões de julgamento, de modo que a discussão em público impede ajustes de pontos de vista e a formação coletiva da decisão. ${ }^{62}$

Outro fator que deveria ser revisto pelo Judiciário é a impossibilidade de se discutir matéria fática nos tribunais superiores. Ora, para que se tenha por base um precedente, necessário analisar se os fatos possuem estrita relação.

Assim, ao verificar que, mesmo com dezenas de reformas legislativas, o Poder Judiciário brasileiro permanece sendo alvo de críticas em função da falta de previsibilidade, busca-se, através do presente artigo, demonstrar uma solução, que seria a adaptação de um sistema misto unificando o civil law à verdadeira teoria dos precedentes. Busca-se, sobretudo, demonstrar a fundamentalidade dos precedentes para a unidade e o desenvolvimento do direito, a clareza e a

\footnotetext{
${ }^{60}$ BOGOSSIAN, Andre; ALMEIDA; Danilo dos Santos. É possível falar em precedente "do Supremo"? A inexistência de julgamentos coletivos. Jota, 5 ago. 2016. Disponível em: <https://www.jota.info/colunas/supra/e-possivel-falar-em-precedente-supremo-05082016>. Acesso em: 14 dez. 2017.

${ }^{61}$ DWORKIN, Ronald. 0 império do direito. 2. ed. São Paulo: Martins Fontes, 2010. p. 287.

62 O ministro Luis Roberto Barroso escreveu sobre o tema, mas sob outro ponto de vista: "A segunda peculiaridade é a transmissão ao vivo, em TV aberta, tanto das sustentações orais (hearings) como dos debates e a deliberação entre os ministros (o que nos Estados Unidos e na maior parte do mundo é feito em conferência interna) e a proclamação dos votos. Embora seja um tanto atípico, é da tradição brasileira que os julgamentos, incluindo a fase dos debates e da deliberação, sejam públicos. 0 que há de muito particular em relação ao Supremo Tribunal Federal é a transmissão ao vivo pela televisão (e simultaneamente pelo canal do Tribunal no youtube). Há muitos críticos desse modelo, sob o fundamento de que a visibilidade dificulta a construção de consensos e traz o risco de politização indevida, na medida em que os ministros, de certa forma, podem ser influenciados pela opinião pública. Na prática, um dos maiores problemas foi que os votos se tornaram mais longos, conforme constatado em pesquisa empírica feita em trabalho de doutorado do qual sou orientador. Apesar de existirem algumas desvantagens, penso que os benefícios são maiores do que as perdas. 0 Brasil é um país no qual o imaginário social supõe que por trás de cada porta fechada estão ocorrendo tenebrosas transações". BARROSO, Luís Roberto. Contramajoritário, representativo e ilumista: os papéis das cortes constitucionais nas democracias contemporâneas. 2015. <https://www.conjur.com.br/dl/notas-palestraluis-robertobarroso.pdf>. Acesso em: 14 dez. 2017.
} 
generalidade, a promoção da igualdade, o fortalecimento institucional, a limitação do poder do Estado, a previsibilidade, a racionalidade econômica e o respeito ao direito. ${ }^{63}$

Caso não haja uma mudança radical em nossos tribunais, especialmente nos superiores, cada vez mais recursos estarão tomando conta do Judiciário, o que acarretará ao descumprimento da razoável duração do processo e da tão sonhada segurança jurídica. ${ }^{64}$

\section{CONCLUSÃO}

Percebe-se que apesar de uma busca incessante pela segurança jurídica, cada vez mais o ordenamento jurídico brasileiro sente a instabilidade das decisões prolatadas pelos tribunais.

De fato, para além dos estudos que visam à reforma do sistema de justiça no sentido de torná-lo mais eficiente e produtivo, existe também uma preocupação centrada na qualidade da justiça entregue ao cidadão, expresso no direito constitucional fundamental do acesso à justiça.

O direito de acesso à justiça configura-se, portanto, como um direito humano fundamental, consagrado no artigo $5^{\circ}$, inciso XXXV, da Constituição Federal, e como tal, conforme registram Cappelletti e Garth, "tem sido progressivamente reconhecido como sendo de importância capital entre os novos direitos individuais e sociais, uma vez que a titularidade de direitos é destituída de sentido, na ausência de mecanismos para sua efetiva reivindicação". ${ }^{65}$

Sem o direito de acesso à justiça todos os demais direitos restariam prejudicados. $\mathrm{Na}$ medida em que o Estado avocou para si a tarefa de solucionar as lides, detendo o monopólio na solução de conflitos, deve empenhar-se em assegurar o pleno acesso à justiça, e a entrega de um prestação jurisdicional correta, justa e adequada.

O desafio da prestação jurisdicional justa está presente de maneira geral em todas as democracias contemporâneas, na quais esteja assegurado o direito de acesso à justiça, e constitui-se um desafio importante a ser enfrentado pelo Estado e pela sociedade. Ela fica, contudo, comprometida, quando casos semelhantes resultam comumente em decisões díspares,

\footnotetext{
${ }^{63}$ MARINONI, Luiz Guilherme. A ética dos precedentes: justificativa do novo CPC. 2. ed. São Paulo: Revista dos Tribunais, 2016.

${ }^{64}$ Precedente é uma decisão que visa o desenvolvimento do Direito. A sua implementação no Brasil é de interesse público, pois ao padronizar uma linha de julgamento, diversas pessoas deixam de se aventurar no Poder Judiciário. Ou seja, com menos pessoas aforando demandas cairá o custo do Estado em manter a "máquina" do Judiciário e, consequentemente, aumentará a renda para aplicação de outras políticas públicas. Ademais, com mais segurança jurídica, menos "politizada" se tornam as decisões dos Tribunais Superiores, isto porque a alteração de precedentes não poderá se dar por conveniência ou interesses obscuros, mas sim por fundamentos densos e baseados em normas e princípios (overruling).

${ }^{65}$ Cf. CAPPELLETTI, Mauro; GARTH, Bryant. Acesso à justiça. Porto Alegre: Fabris, 1988.
} 
uma situação que a correição dos precedentes procura minorar, de maneira a garantir maior isonomia nas decisões prolatadas, cumprindo dessa maneira o mandamento constitucional do acesso à justiça, de resto assegurado também na Convenção Americana de Direitos Humanos e na própria Declaração Universal dos Direitos Humanos.

Sem coerência e integridade nos julgamentos é inviável falarmos em pleno acesso à justiça, uma vez que, em tese, quem possui condições de arcar com melhores profissionais recebe um melhor retorno por parte do Estado.

Os mecanismos tradicionais de prestação jurisdicional já não estão sendo suficientes para dar conta da demanda que assoberba a justiça, o que enseja a pesquisa de novas técnicas, métodos e processos que se voltem a assegurar a jurisdição justa, efetiva e eficaz. Nesse sentido, a isonomia que se almeja por meio da construção de precedentes "seguros" constitui-se em importante processo de inovação social, com potencial para auxiliar na importante tarefa de realizar a justiça. Contudo, não basta apenas a implementação de precedentes; precisa-se de uma reforma nos métodos de julgamento, ou melhor, no sistema deliberativo dos tribunais.

Em suma, a conclusão que o presente artigo nos traz é a de que ainda não existem precedentes no Brasil. 0 que há, são decisões esparsas ou jurisprudência que procuram se encaixar nos princípios norteadores do common law, mas, que na verdade, ainda precisam de acurado estudo por parte dos profissionais do direito, em especial dos ministros dos tribunais superiores.

\section{REFERÊNCIAS}

BARROSO, Luís Roberto. Contramajoritário, representativo e ilumista: os papéis das cortes constitucionais nas democracias contemporâneas. 2015. <https://www.conjur.com.br/dl/notaspalestra-luis-robertobarroso.pdf>. Acesso em: $14 \mathrm{dez} .2017$.

BENDITT, Theodore M. The rule of precedent. Precedent in law. Oxford: Clarendon Press, 1987.

BISHOP, Joel Prentiss. Common law and codification or the Common law as a system of reasoning - How and why essential to good government; what its perils, and how averted. Chicago: Law Book Publishers, 1888.

BOGOSSIAN, Andre; ALMEIDA; Danilo dos Santos. É possível falar em precedente "do Supremo"? A inexistência de julgamentos coletivos. Jota, 5 ago. 2016. Disponível em:

<https://www.jota.info/colunas/supra/e-possivel-falar-em-precedente-supremo-05082016>.

Acesso em: 14 dez. 2017.

BRASIL. Constituição Federal. Diário Oficial da República Federativa do Brasil, Brasília, 5 out. 1988. Disponível em: <http://www.planalto.gov.br/ccivil_03/constituicao/constituicao.htm>. Acesso em: 14 dez. 2017. 
BRASIL. Lei $n^{\circ} 9.868$, de 10 de novembro de 1999. Dispõe sobre o processo e julgamento da ação direta de inconstitucionalidade e da ação declaratória de constitucionalidade perante o Supremo Tribunal Federal. Diário Oficial da República Federativa do Brasil, Brasília, 11 nov. 1999. Disponível em: <http://www.planalto.gov.br/Ccivil_03/Leis/L9868.htm>. Acesso em: 14 dez. 2017.

BRASIL. Lei n 13.105, de 16 de março de 2015. Código de Processo Civil. Diário Oficial da República Federativa do Brasil, Brasília, 17 mar. 2015. Disponível em:

<http://www.planalto.gov.br/ccivil_03/_ato2015-2018/2015/lei//13105.htm>. Acesso em: 14 dez. 2017.

BRASIL. Senado Federal. Emenda apresentada pelo Senador Edison Lobão à PEC $n^{\circ}$ 10/2017. 2017. Disponível em: < http://legis.senado.leg.br/sdleg-

getter / documento?dm=6456125\&disposition=inline> . Acesso em: 14 dez. 2017.

BRASIL. Superior Tribunal de Justiça. Recurso Especial $n^{\circ}$ 828.106/SP. Vilar Comércio de Bebidas Ltda e Fazenda Nacional. Relator: Ministro Teori Albino Zavascki. 15 de maio de 2006. Disponível em:

<https://ww2.stj.jus.br/processo/revista/documento/mediado/?componente=ITA\&sequencial=6 23920\&num_registro=200600690920\&data=20060515\&formato=PDF>. Acesso em: 14 dez. 2017.

BRASIL. Supremo Tribunal Federal. Ação Cautelar 1.550-2-RO. Companhia de Águas e Esgotos de Rondônia - CAERD e Município de Guajará Mirim. Relator: Ministro Gilmar Mendes. 6 de fevereiro de 2007. Disponível em:

$<$ http: //redir.stf.jus.br/paginadorpub/paginador.jsp?docTP=AC\&doclD=456054>. Acesso em: 14 dez. 2017.

BRASIL. Supremo Tribunal Federal. Constitucionalidade do instituto da repercussão geral é questionada no Supremo. 19 jan. 2010. Disponível em:

<http: / / www.stf.jus.br/portal/cms/verNoticiaDetalhe. asp?idConteudo=118645>. Acesso em: 14 dez. 2017.

BRASIL. Supremo Tribunal Federal. Reclamação 2.363. Município de Capitão Poço, Presidente do Tribunal Regional do Trabalho da $8^{\text {a }}$ Região e Iraneide Galdino Moreira e outro. Relator: Ministro Gilmar Mendes. 1 de abril de 2005. Disponível em:

<http://redir.stf.jus.br/paginadorpub/paginador.jsp?docTP=AC\&docID=365588>. Acesso em: 14 dez. 2017.

BRASIL. Supremo Tribunal Federal. Reclamação 7.569-SP. Município de São Paulo, Presidente do Tribunal de Justiça do Estado de São Paulo e Luiz Antônio Mariano Lozano e outro. Relatora: Ministra Ellen Gracie. 19 de novembro de 2009. Disponível em:

<http: //redir.stf.jus.br/paginadorpub/paginador.jsp?docTP=AC\&docID=606662>. Acesso em: 14 dez. 2017.

BRASIL. Supremo Tribunal Federal. Reclamação: Cabimento e Senado Federal no Controle da Constitucionalidade - 4. Informativo STF $n^{\circ}$ 454. 1-2 fev. 2007. Disponível em:

<http://www.stf.jus.br/arquivo/informativo/documento/informativo454.htm>. Acesso em: 14 dez. 2017. 
BRASIL. Supremo Tribunal Federal. Súmula 634. 13 out. 2003. Disponível em:

<http: / / www.stf.jus.br/portal/jurisprudencia/menuSumarioSumulas.asp?sumula=2023>. Acesso em: 14 dez. 2017.

BRASIL. Supremo Tribunal Federal. Súmula Vinculante 3. 6 jun. 2007. Disponível em:

<http: //www.stf.jus.br/portal/jurisprudencia/menuSumario.asp?sumula=1191 >. Acesso em: 14 dez. 2017.

BRASIL. Supremo Tribunal Federal. Questão de ordem em Agravo de Instrumento 760.358-SE. Unão e Jacileide Dantas dos Santos. Relator: Ministro Gilmar Mendes. 19 de novembro de 2009. Disponível em: <http://redir.stf.jus.br/paginadorpub/paginador.jsp?docTP=AC\&doclD=608471> . Acesso em: 14 dez. 2017.

BRASIL. Supremo Tribunal Federal. Questão de ordem em medida cautelar em ação cautelar 1.549 - RO. Companhia de Águas e Esgotos de Rondônia - CAERD e Município de Cerejeiras. Relator: Ministro Celso de Mello. 13 de fevereiro de 2007. Disponível em: <http: / / redir.stf.jus.br/paginadorpub/paginador.jsp?docTP=AC\&doclD=443436>. Acesso em: 14 dez. 2017.

BRASIL. Superior Tribunal de Justiça. Questão de ordem no agravo de instrumento ${ }^{\circ}$ 1.154.599-SP. Cosan S/A Indústria e Comércio e outros, e Fazenda Nacional. Relator: Ministro Cesar Asfor Rocha. 16 de fevereiro de 2011. Disponível em:

<https://ww2.stj.jus.br/processo/revista/documento/mediado/?componente=ITA\&sequencial=9 37926\&num_registro=200900659392\&data=20110512\&formato=PDF>. Acesso em: 14 dez. 2017.

BUSTAMANTE, Thomas da Rosa de. Teoria do precedente judicial: a justificação e a aplicação de regras jurisprudenciais. São Paulo: Noeses, 2012.

CAMARGO, Luiz Henrique Volpe. A força dos precedentes no moderno processo civil brasileiro. In: Teresa Arruda Alvim Wambier (Coord.). Direito jurisprudencial. São Paulo: Revista dos Tribunais, 2012. p. 556.

CAPPELLETTI, Mauro; GARTH, Bryant. Acesso à justiça. Porto Alegre: Fabris, 1988.

CROSS, Rupert; HARRIS, J. W. Precedent in English law. Oxford: Clarendon Press, 1991.

DWORKIN, Ronald. Levando os direitos a sério. São Paulo: Martins Fontes, 2002.

DWORKIN, Ronald. 0 império do direito. 2. ed. São Paulo: Martins Fontes, 2010.

ESTADOS UNIDOS. Suprema Corte dos Estados Unidos. Brown v. Board of Education. 17 maio 1954. Disponível em: <http://caselaw.findlaw.com/us-supreme-court/347/483.html>. Acesso em: 14 set. 2017.

LIMA, Augusto César Moreira. Precedentes no Direito. São Paulo: LTr, 2001.

MACCORMICK, Neil; SUMMERS, Robert S. (Coord.). Interpreting precedents: a comparative study. London: Dartmouth, 1997. 
MAGRO, Maíra. Estudo aponta textos idênticos em decisões do STF. Valor, Brasília, 12 fev. 2016. Disponível em: <http: / www.valor.com.br/legislacao/4432396/estudo-aponta-textos-identicosem-decisoes-do-stf> Acesso em: 14 dez. 2017.

MANCUSO, Rodolfo de Camargo. Divergência jurisprudencial e súmula vinculante. 4. ed. São Paulo: Revista dos Tribunais, 2010.

MARINONI, Luiz Guilherme. A ética dos precedentes: justificativa do novo CPC. 2. ed. São Paulo: Revista dos Tribunais, 2016.

MARINONI, Luiz Guilherme. A força dos precedentes: estudos dos cursos de Mestrado e Doutorado em Direito Processual Civil da UFPR. 2. ed. Salvador: JusPodivm, 2012.

MARINONI, Luiz Guilherme. Julgamento nas cortes supremas: precedente e decisão do recurso diante do novo CPC. São Paulo: Revista dos Tribunais, 2015.

MARINONI, Luiz Guilherme. Precedentes obrigatórios. 2. ed. São Paulo: Revista dos Tribunais, 2011.

MELLO, Patrícia Perrone Campos. Precedentes - O desenvolvimento judicial do direito no constitucionalismo contemporâneo. Rio de Janeiro: Renovar, 2008.

ODAHARA, Bruno Periolo. Um rápido olhar sobre o stare decisis. In: MARINONI, Luiz Guilherme. A força dos precedentes: estudos dos cursos de Mestrado e Doutorado em Direito Processual Civil da UFPR. 2. ed. Salvador: JusPodivm, 2012.

PEDRON, Flávio Quinaud. Mutação constitucional na crise do positivismo jurídico: história e crítica do conceito no marco da teoria do Direito como integridade. Belo Horizonte: Arraes, 2012.

STRECK, Lenio Luiz; ABBOUD, Georges. 0 que é isto - o precedente judicial e as súmulas vinculantes? Porto Alegre: Livraria do Advogado, 2013.

VALE, André Rufino do. A deliberação no Supremo Tribunal Federal: ensaio sobre alguns problemas e perspectivas de análise teórica. In: FELLET, Andre; NOVELINO, Marcelo (org.). Constitucionalismo e Democracia. Salvador: Juspodivm, 2013, p. 329-348.

ZOBELL, Karl M. Division of Opinion in the Supreme Court: a history of judicial disintegration. In: Cornell Law Quaterly Review, v. 44, p. 186-214, 1959.

\section{COMO FAZER A REFERÊNCIA DO ARTIGO (ABNT):}

ANDREASSA JUNIOR, Gilberto; BARBOSA, Claudia Maria. Teoria dos precedentes e sua incompatibilidade com o sistema deliberativo dos tribunais superiores. Revista Eletrônica do Curso de Direito da UFSM, Santa Maria, RS, v. 12, n. 3, p. 861-888, dez. 2017. ISSN 1981-3694. Disponível em: <https://periodicos.ufsm.br/revistadireito/article/view/26773>. Acesso em: dia mês. ano. doi: http://dx.doi.org/10.5902/1981369426773. 